\title{
The Impact of Relationship Quality Between Social Media Influencers and Their Followers on Brand Purchase Intention
}

\author{
Tsung-Hsien Kuo ${ }^{1} \&$ Han-Kuang Tien ${ }^{2}$ \\ ${ }^{1}$ Department of Banking and Finance, Tamkang University, New Taipei, Taiwan \\ ${ }^{2}$ Department of International Trade, School of Business, Chinese Culture University, Taipei, Taiwan \\ Correspondence: Han-Kuang Tien, Department of International Trade, School of Business, Chinese Culture \\ University, No. 231, Sec. 2, Chien-Kuo S. Rd., Taipei, Taiwan. E-mail: hktien@sce.pccu.edu.tw
}

Received: September 18, $2021 \quad$ Accepted: October 25, $2021 \quad$ Online Published: November 8, 2021

doi:10.5539/ijms.v13n4p1 URL: https://doi.org/10.5539/ijms.v13n4p1

\begin{abstract}
Social media influencers (SMI) have been shown to influence the purchase decision-making of their followers. In this respect, it is necessary to explore the interactive relationship between them, i.e., relationship quality. Researchers will not know the extent to which social media influencers affect their followers and their persistence of persuasion until they understand the SMI-follower relationship quality.

This study focused on whether the SMI-follower relationship quality enables followers to transfer their trust in SMIs and affects their attitude toward the advertised or recommended product and brand. Furthermore, it explored whether followers' skeptical attitude toward advertising moderates the relationship between the SMI-follower relationship quality and trust transference, and whether followers' self-monitoring moderates the relationship between their advertising skepticism and trust transference.

This study distributed survey questionnaires online, and obtained a total of 235 valid copies. The data were used to conduct path analysis through the software PROCESS. The empirical data showed that the higher the SMI-follower relationship quality, the more likely are the followers to transfer their trust in SMIs to the advertised or recommended product or brand. In addition, it was found that trust transference positively mediates the impact of relationship quality on brand attitude. Further, the results indicated that the followers' high level of advertising skepticism negatively moderates the impact of SMI-follower relationship quality on trust transference, and that a high level of self-monitoring inhibits the negative moderating effect of advertising skepticism on the relationship between SMI-follower relationship quality and trust transference to a larger extent.
\end{abstract}

Keywords: social media influencer, relationship quality, trust transference, advertising skeptical character, self-monitoring

\section{Introduction}

Social media influencers (SMIs), usually celebrities or opinion leaders (Enke \& Borchers, 2019; Camplee \& Farrell, 2020; Boerman, 2020), have the capacity to influence consumers' purchase decision-making (Lou \& Yuan, 2019) via social media. McGuire (1989) proposed the input-output persuasion matrix and suggested the five elements that influence persuasion, namely: (1) source, (2) message, (3) channel, (4) receiver, and (5) destination. However, only the source, message, and receiver have been the focus of previous research. The element "source" explores how credibility and attraction influence the purchase behavior of followers (Ki et al., 2020). The element "message" examines which of the two types of value, namely informative value and entertainment value, generate the purchase intention of the brand that SMIs recommend; it was found that informative value has stronger effects (Lou \& Yuan, 2019). Lastly, the element "receiver" investigates the parasocial interaction relationship between SMIs and their followers, which could increase the intention of the latter to purchase a particular brand or product.

Based on the relationship management theory, the management of SMI-follower relationship is a key factor in the SMI economy (Dhanesh \& Duthler, 2019). Persuaders must win the trust of others first before they can convince and influence them (O'Shaughnessy \& O'Shaughnessy, 2004). Previous research has already confirmed that the parasocial interaction relationship between SMIs and followers is unidirectional. 
Consequently, this study holds that it is necessary to explore the quality of relationship between SMIs and their followers to understand the extent to which the former influence the latter and the persistence of their persuasion (Arjun \& Holbrook, 2001; Dhanesh \& Duthler, 2019).

Brand manufacturers have recognized that releasing brand-related information via SMIs is an effective marketing strategy. However, there have been SMIs who have violated government laws and/or social norms through thoughtless social media posts. For instance, the knowledge-based YouTuber Mrs. Science violated the pharmaceutical law when she advertised on her YouTube channel in 2019. Another was a YouTuber who made improper remarks about Penghu (a tourist destination in Taiwan) while shooting a video for a YouTube channel. These mistakes, when they become public, exert a negative impact on the SMIs and reduce people's trust in them. Relationships are dynamic and can only be maintained if they are mutually beneficial for both parties (Thibau \& Kelley, 1959). Therefore, the SMI-follower relationship quality plays an important role in maintaining their relationship.

Based on the aforementioned, this research aims to explore the following questions:

(1) Does the SMI-follower relationship quality results in trust transference in the SMIs and affects the followers' attitude toward the brand being advertised?

(2) Does followers' advertising skepticism moderate the impact of SMI-follower relationship quality on trust transference?

(3) Does followers' self-monitoring moderate the relationship between their advertising skepticism and trust transference?

\section{Literature Review}

\subsection{Social Media Influencer}

Ki and Kim (2019) defined SMIs as independent third-party endorsers with a sizeable number of social media followers, who create and send posts containing texts, pictures, or videos on social media, in which they integrate their daily life and experience into brand promotion (De Veirman, Cauberghe, \& Hudders, 2017).

Campell and Farrel (2020) discussed the influence of SMIs based on the number of their followers and classified them into five types: (1) celebrity influencers (1 million + followers, the rich and famous); (2) mega-influencers ( 1 million + followers, the everyday celebrity); (3) macro-influencers $(100 \mathrm{k}-1 \mathrm{~m}$ followers, the sweet spot); (4) micro-influencers $(10 \mathrm{k}-100 \mathrm{k}$ followers, the rising star), and (5) nano-influencers $(0-10 \mathrm{k}$ followers, the newcomers). The number of their followers represents how much they are liked and how far their influence extends. However, it is not always true that the more followers they have, the better it is. De Veirman, Cauberghe, and Hudders (2017) found that SMIs with a larger number of followers are suitable for promoting divergent products, while those with a smaller number of followers are suitable for promoting unique products.

In addition, previous literatures noted that personality traits and content are two factors that enable SMIs to attract followers. In terms of personality traits, it was found that SMIs with a high degree of authenticity, attractiveness, and intimacy (Audrezet, De Kerviler, \& Moulard, 2018; Lou \& Yuan, 2019; Ki, Cuevas, Chong, $\&$ Lim, 2020) are likely to gain more followers. Further, those whose posts are informative, provide visual pleasure, and have entertainment value are likely to attract followers (Ki \& Kim, 2019; Stubb \& Colliander, 2019; Lou \& Yuan, 2019).

According to the human brand theory by Thomson (2006), media personas can be developed into human brands. Marshall (2010) believed that some SMIs, like traditional celebrities, have media personas which can be successfully developed into human brands later on. Although SMIs and celebrities have similarities, they also differ in some aspects. Celebrities enjoy public recognition and fame (McCracken, 1989), whereas SMIs are liked by followers for their grassroots (Ki \& Kim, 2019). Also, SMIs enjoy some fame on one or multiple social media; they differ from traditional celebrities (i.e., TV celebrities) in terms of the content they provide and the source of their audience. They are usually perceived as friends of the general public and may establish close relationships with them whereas celebrities are usually those being looked up to by ordinary people (Dhanesh \& Duthler, 2019). Therefore, it is more proper to describe the relationship between celebrities and fans as "parasocial", which is unidirectional, while the relationship of SMIs with their followers could be bidirectional as they can easily reply and interact with them (Yuan \& Lou, 2020). In this respect, this study believes that it is necessary to explore the SMI-follower relationship quality.

\subsection{SMI Endorsement and Persuasion}

Research revealed that SMIs are more closely connected with their audience compared to endorsers utilizing 
traditional advertising; the community and cultural capital of SMIs enable them to be more efficient in obtaining brand benefits (Chu, Kamal, \& Kim, 2019). For SMIs, one way to cash in on their influence is to cooperate with brand manufacturers, making followers have a strong desire to use the same goods and services as them (Stoldt, Wellman, \& Ekdale, 2019).

McGuire (1989) proposed the input-output persuasion matrix and suggested the five elements that influence persuasion, namely: (1) source, (2) message, (3) channel, (4) receiver, and (5) destination. However, only the source, message, and receiver have been the focus of previous research. The element "source" explores how credibility and attraction influence the purchase behavior of followers (Ki et al., 2020). The element "message" examines which of the two types of value, namely informative value and entertainment value, generate the purchase intention of the brand that SMIs recommend; it was found that informative value has stronger effects (Lou \& Yuan, 2019). Lastly, the element "receiver" investigates the parasocial interaction relationship between SMIs and their followers, which could increase the intention of the latter to purchase a particular brand or product.

To keep their influence lasting and effective, it is necessary for SMIs to establish and maintain good relationships with their followers. As described by Thibau and Kelley (1959), relationships are dynamic, and they should be mutually beneficial to both parties to persist. Thus, the SMI-follower relationship quality plays an important role in maintaining the relationship.

\subsection{Relationship Quality}

Previous studies pointed out that a transaction is likely to be completed if the two parties involved have a long-term relationship (Lovelock, 1983). During service transaction, service quality is necessary and relationship quality is indispensable. Relationship quality is a construct that measures the strength of the relationship between the buyer and the seller (Crosby, Evans, \& Cowles, 1990); it is the overall evaluation of the strength of the relationship, assessing whether the needs and expectations of both parties are met. Therefore, a high relationship quality between the seller and the buyer is helpful in improving the performance of the seller.

When SMIs create posts to promote a certain brand, they are working as a salesman, marketing the brand and persuading their followers to purchase its products. In this respect, the SMI-follower relationship quality will affect their followers' purchase intention. Relevant literature pointed out that relationship quality has three constructs, namely: (1) trust, (2) commitment, and (3) satisfaction (Moorman, Deshpande, \& Zalman, 1993; Morgan \& Hunt, 1994; Oliver, 1997; Kumar \& Pansari, 2016; Itani, Kassar, \& Loureiro, 2019). Among them, trust is the key factor that enables a relationship to last (Santouridis \& Veraki, 2017).

Morgan and Hunt (1994) found that a high relationship quality is produced when both parties believe that their relationship is worth maintaining, which means that it is based on trust. Therefore, SMIs must be able to transfer their trust in the brand to their followers so that a relationship between the brand and the followers can be established. In this way, they can make their followers generate brand purchase intentions.

\subsection{Trust Transference}

Trust transference theory holds that when individuals trust certain objects, they tend to place their trust in unknown objects related to the latter (Doney \& Cannon, 1997). Similarly, when we trust a person or an entity, we also trust relevant persons or entities through trust transference (Zhao, Huang, \& Su, 2019).

Doney and Cannon (1997) provided the five processes that establish trust between the seller and buyer, which are (1) calculative-based, (2) prediction-based, (3) capability-based, (4) intentionality-based, and (5) transference-based. This research applied transference-based trust to explore the SMI-follower relationship quality.

Transference-based trust means that people transfer their trust in individuals (or websites) towards certain objects that the latter recommend despite the former not having direct contact or being unfamiliar with the objects (Milliman \& Fugate, 1988). For example, when a trusted blog recommends a link to a website (or product), the readers are likely to transfer their trust in the blog to the recommended website (or product).

Trust is an important construct for relationship quality (Ganesan \& Hess, 1997; Johnson \& Grayson, 2005). This study aims to explore whether the trust of followers in SMIs will be transferred to the product recommended by the latter, thus influencing the attitude of the former toward the product. It also approaches whether trust transference has mediating effects on the relationship between SMI-follower relationship quality and followers' attitude toward the brand recommended by SMIs. 


\subsection{Brand Attitude}

Howard (1989) defined attitude as the extent to which consumers expect that a brand can meet their special needs. Consumers' attitude toward brands (i.e., their preference) can be evaluated through their subjective cognition. Brand attitude is the overall evaluation of the brand based on its various attributes, such as price, appearance, function, and quality (Lee, Lee, \& Yang, 2017).

Fishbein and Ajzen (1975) referred to brand attitude as the overall evaluation of consumers after experiencing a specific brand. This study adopted the definition of Aaker and Fournier (1995) who referred to brand attitude as consumers' overall emotional and affective evaluation of a brand. Assael (2004) divided brand attitude into (1) brand belief, which is the consumers' perceived characteristic of the brand; (2) brand evaluation, which is the extent to which the brand is liked by the consumers; and (3) purchase intention, which refers to the consumers' tendency to purchase the products of the brand.

\subsection{Advertising Skepticism}

Advertising skepticism refers to consumers' negative attitude (or disbelief) toward advertising claims. Skepticism means that consumers realize advertisers have some motives behind their advertising, such as guidance and persuasion, which may lead to biased communication (Boush, Friestad, \& Rose, 1994; Brucks, Armstrong, \& Goldberg, 1988). It is also described as the way in which consumers evaluate and process advertising messages. When faced with advertising, consumers with a skeptical attitude tend to recall relevant negative experiences (Campbell \& Kirmani, 2000), resulting in a negative response. Thus, they are unable to be persuaded by the advertiser (Obermiller, Spangenberg, \& Maclachlan, 2005). Obermiller, Spangenberg, and MacLachlan (2005) developed the SKEP scale to measure the consumers' tendency of disbelief toward advertising messages. They found that consumers' doubts on the authenticity of advertising reduce the value of information transmission. Consequently, Darby and Karni (1973) suggested that consumers are skeptical about the advertisement content (quality, durability and performance) of experience and credence goods.

Darby and Karni (1973) classified products into three categories based on people's degree of trust in advertising, namely (1) search products, which are those with information that can be easily searched prior to purchase; (2) experience products, which are those that need to be experienced or used to obtain information; and (3) credence products, which are products with relevant information that can neither be searched nor known via short-term use. In this respect, Feick and Gierl (1996) pointed out that consumers are more skeptical about credence products than experience ones, and have a higher level of skepticism for high-priced experience products than low-priced ones.

\subsection{Self-Monitoring}

The concept of self-monitoring is based on classical pragmatism, and is regarded as a personality trait. Snyder (1979) proposed that individuals alter their own behavior according to changes in the external environments, which has stable and measurable individual differences. Individuals can maintain their positive self-image through self-monitoring (Gangestad \& Snyder, 2000).

Nantel and Strahle (1986) referred to self-monitoring as the individual's way of paying attention to the surroundings; the information they get is utilized as a clue about how they should present themselves, and how they should alter their behavior. Therefore, this personality trait makes people become potentially affected by others' remarks and attitudes, which could lead to a change in their behavior (Fine \& Schumann, 1992).

Self-monitoring can be divided into high and low levels. High self-monitors are highly sensitive and good at capturing others' emotions during an interaction (Synder, 1979). They are able to alter their behavior according to what they have observed, for which they show high social adaptation (Lippa, 1976). High self-monitors are seen as social chameleons, who change their behavior to present a self-image that conforms to a given situation (Bedeian \& Day, 2004). By contrast, low self-monitors often follow their feelings and show their actual attitude when presenting themselves. They do not care much about social contexts or situations, or examine whether social contexts are helpful to their behavior; they exhibit their behaviors with their inner attitude, values, and belief as their guidance. Low self-monitors are regarded as those who are loyal to themselves, for their performance is stable and does not change according to external situations (Bedeian \& Day, 2004). Moreover, Jenkins (1993) believed that self-monitoring may change due to external influences, despite being considered as a stable personality trait. For instance, the elderly are more likely to act based on their own experience and belief, and are less likely to change their thinking compared with the younger individuals who tend to have a higher level of self-monitoring.

Lavine and Snyder (1996) confirmed that low self-monitors are influenced by "messages making appeals to 
values", whereas high self-monitors are impacted by "appeals to status". In addition, it has been proven empirically that high self-monitors prefer prestigious brands that show their social status (Becherer \& Richard, 1978). DeBono (2006) found that high self-monitors make judgments about the quality of a product based on its appearance, whereas low self-monitors make judgments via its performance.

\section{Research Methods}

\subsection{Research Framework}

Based on the relationships between variables stated above, this study explored the impact of the SMI-follower relationship quality on brand attitude via trust transference. Moreover, advertising skepticism and self-monitoring were set as moderators. The research framework is shown as follows.

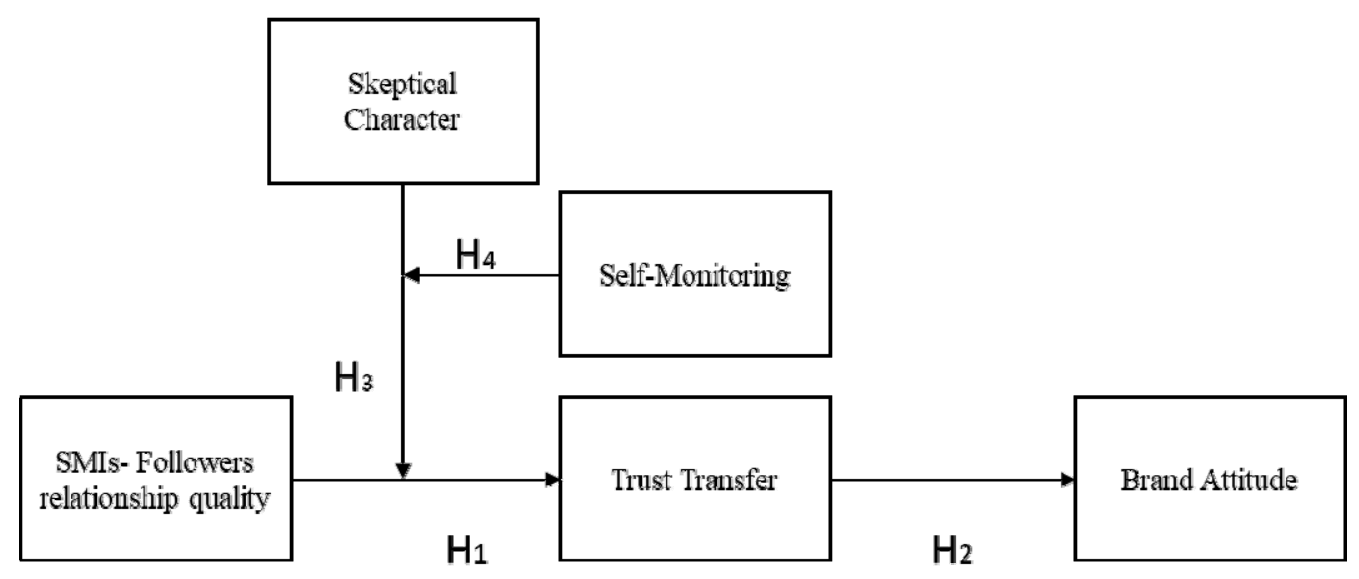

Figure 1. Research framework

\subsubsection{SMI-Follower Relationship Quality, Trust Transference, and Brand Attitude}

$\mathrm{SMI} /$ celebrity endorsement and product marketing are common marketing strategies that brand manufacturers adopt. Previous studies have already pointed out that endorsers must have professionalism, credibility, reliability, persuasiveness, and preference. In addition, consumers' familiarity with endorsers affects their perception of the recommended products, influencing their purchase intention (Stoldt, Wellman, \& Ekdale, 2019).

Previous researches on relationship quality mainly focused on the interaction between enterprises/brands and customers. Crosby, Evans and Cowles (1990) first introduced the blogger-reader relationship quality. Relationship quality is the foundation of good cooperative relationships. Through long-term operation and maintenance, a blogger is able to establish professionalism to his/her readers. By sharing reliable information, the blogger is able to convince the readers that he/she is trustworthy and cares about their interests.

Wang et al. (2015) pointed out that readers tend to compare the differences between themselves and the bloggers. The closer the readers get to the actual or ideal image of the blogger, the better the blogger-reader relationship quality. When the satisfaction of readers is sufficient to make them commit to maintaining a long-term relationship with the blogger, they become willing to adopt an inclusive and trusting attitude towards the blogger (Fournier, 1998). The study by Wang et al. (2015) found that the higher the blogger-reader relationship quality, the more positive is its impact on readers' word-of-mouth product transmission. This confirmed that relationship quality truly influences the relationship between the SMIs and the followers.

Trust constitutes the basis of relationship quality. Stewart (2003) explored consumers' trust transference between shopping websites, and found that consumers believed that shopping websites have similarities and interactivity. If consumers trust one website, they would trust an unknown website to some extent. Bergami and Bagozzi (2000) believed that when customers identify with the company, they will have a sense of belonging and identity, making them show positive attitudes and behaviors like taking pride in their work.

Moey and Kincade (2003) pointed out that attitude is one's tendency to react to certain people, matters, and issues, giving a persistent and consistent evaluation which could be either positive or negative. It is also an antecedent of consumers' behavior, which can directly predict their purchase behavior. When customers identify with a company, they will support it and continuously purchase its products, making it more competitive than its 
rivals in the long run (Armstrong \& Kolter, 2000). Moreover, Smith (1998) observed that readers were willing to establish a long-term relationship with their trusted bloggers, believing that the latter are capable of meeting their needs and act in their interests.

This research holds that SMIs share some similarities with bloggers. Thus, based on the above statements, the following hypotheses are proposed:

H1: The higher the SMI-follower relationship quality, the more likely it is for the followers to transfer their trust in SMIs towards products that the latter recommend.

H2: The higher the extent of trust transference, the more positive followers' attitude toward the brand endorsed by SMIs.

\subsubsection{SMI-Follower Relationship Quality, Trust Transference, and Advertising Skepticism}

Mangleburg and Bristol (1998) noted that consumers have a tendency toward disbelief of advertising claims because they realize that advertisers have certain motives behind the advertising. Furthermore, Obermiller and Spangenberg (1998) found that consumers with a higher level of advertising skepticism take a more negative attitude toward advertising than those with a lower level of skepticism. In addition, it was confirmed that consumers with a high level of skepticism do not rely on advertising much, so they tend to avoid it because they do not believe in persuasive stimuli like suggestions, proposals, or changed messages. Therefore, they are considered as cautious and careful (Obermiller \& Spangenberg, 1998). These explain why consumers with different levels of skepticism make different responses.

Hwang and Jeong (2016) revealed that consumers' advertising skepticism affect their purchase intention; more specifically, consumers with a high level of skepticism often take a negative attitude toward advertising, decreasing their purchase intention.

Also, Lee and Hong (2019) found that a high SMI-follower relationship quality is more likely to generate trust transference. Meanwhile, a high level of skepticism results in a negative attitude toward advertising. Therefore, this research infers that skeptical character has moderating effects; that is, the higher the level of consumers' advertising skepticism, the less likely the followers will transfer their trust in SMIs towards brands endorsed by the latter. Based on the above, the following hypothesis is proposed:

H3: Followers' high level of advertising skepticism negatively moderates the relationship between SMI-follower relationship quality and trust transference.

\subsubsection{SMI-Follower Relationship Quality, Trust Transference, Advertising Skepticism, and Self-Monitoring}

As previously mentioned, the higher the level of advertising skepticism, the more likely it is to negatively moderate the relationship between SMI-follower relationship quality and trust transference. Self-monitoring is a personality trait; individuals with high self-monitoring are susceptible to external information flow and have the tendency to exhibit herd mentality (Bikhchandani et al., 2011).

SMIs represent an ideal state that followers expect to get into, so followers with high self-monitoring are likely to change their behavior or appearance to get close to the "ideal state", or to conform to the viewpoint of the public. Enterprises can use this to attract the attention of followers and recommend products to them, which could lead to consumer purchase behaviors. By contrast, it is difficult to influence followers with low self-monitoring via the recommendation of SMIs. Therefore, consumers with high self-monitoring are likely to inhibit the negative moderating effect of skepticism on SMI-follower relationship quality and trust transference (Ferguson, Lau, \& Phau, 2016; Kauppinen-Räisänen et al., 2018; Pornsakulvanich, 2018). Accordingly, this research proposes the following hypothesis:

H4: Followers' high self-monitoring inhibits the negative moderating effect of advertising skepticism on the relationship between SMI-follower relationship quality and trust transference.

\subsection{Operational Definition of Research Variables and Question Items}

This section discusses the operational definitions of the five variables being explored, namely: (1) SMI-follower relationship quality, (2) trust transference, (3) brand attitude, (4) advertising skepticism, and (5) self-monitoring. Also, the scales that measure these variables are presented. The questionnaire used for this research consisted of short-answer and multiple-choice questions. The multiple-choice questions were scored using a seven-point Likert scale (1 for strongly disagree and 7 strongly agree).

\subsubsection{Relationship Quality}

This research evaluated the relationship between SMIs and followers using the items from the brand relationship 
quality scale developed by Huber et al. (2010), which consists of eight questions. Consequently, the study by Itani, Kassar and Loureiro (2019) provided the three constructs of relationship quality, which are trust, commitment, and satisfaction. Therefore, with the aid of experts, this research selected three questions, one for each construct, from the brand relationship quality scale. The questions are as follows:

1) I think this SMI should be like a good friend of mine.

2) I believe in the professional knowledge of this SMI.

3) I feel disappointed and lost if I do not watch the videos or browse the articles posted by this SMI for a period of time.

\subsubsection{Trust Transference}

This study referred to the trust transference scales by Doney and Cannon (1997), Zhao, Huang and Su (2019), and Liu et al. (2018), and selected three questions through experts' discussion. The questions included are as follows:

1) I think that this SMI is sincere and reliable.

2) This SMI recommend products sincerely, which makes me think that the products can be trusted.

3) The products recommended by this SMI are reliable.

\subsubsection{Brand Attitude}

This research divided brand attitude into three constructs, namely cognitive, emotional, and behavioral, as proposed by MacKenzie, Lutz and Belch (1986). Based on these constructs, three items for measuring the brand attitude were selected from the scale by Rosenberg et al. (1960). These are as follows:

1) I think the brand (or products) recommended by this SMI is trustworthy.

2) I think the brand (or products) recommended by this SMI can meet my expectations.

3) I think I have a strong sense of identity with the brand (or products) recommended by this SMI.

\subsubsection{Advertising Skepticism}

This study adopted the skeptical character scale developed by Zhang, Ko and Carpenter (2016), which incorporated the word-of-mouth skepticism scale modified by Obermiller and Spangenberg (1998) and Tan (2002). The skeptical character scale includes three dimensions, namely (1) trustfulness of the message sender, (2) motives of the message sender, and (3) identity of the message sender. The present study selected three questions and revised them. The revised questions are as follows:

1) I can hardly get the truth from the articles or videos posted by SMIs.

2) Generally, the articles or videos posted by SMIs do not truthfully present the totality of the products.

3) Most SMIs intentionally lead me in forming my views on certain products.

\subsubsection{Self-Monitoring}

This study adopted the self-monitoring scale compiled by Lennox and Wolf (1984) based on the scale developed by Synder (1974). It consists of two dimensions which are the ability to modify self-presentation and the sensitivity to the expressive behavior of others. For the current research, three out of 13 items from the study by O'cass (2000), which conducted factor analysis of the self-monitoring scale, were selected:

1) I am able to change myself in order to leave a good first impression on others.

2) I am able to alter my behavior to adapt to the environment.

3) I can easily change my behavior when the situation requires it.

\subsection{Research Design}

\subsubsection{Research Participants}

The study explored whether SMIs influence their followers' impression and purchase intention of the products they recommend by establishing relationships with their followers. There are various kinds of SMIs, and respondents have different preferences for SMIs. To ensure that research participants were not limited to a particular type, the respondents were asked to write down the SMIs who they like and the category of the recommended products. 


\subsubsection{Survey Method}

The participants of this study were Internet users who had been following a certain SMI for a long time. The SMI being followed must have posted commercial advertising. Surveycake was utilized as a tool to conduct an online survey; the questionnaires were distributed through various Internet platforms.

\section{Data Processing and Statistical Analysis}

\subsection{Samples and Descriptive Statistics}

The questionnaire survey was conducted between April 19, 2020 and May 2, 2020 through Surveycake. A total of 363 questionnaires were collected. If the respondents were long-time followers of an SMI who had not advertised in the past, their data were not included in the study. After removing the invalid questionnaires, 245 were recognized as valid, and the effective recovery rate was $67.49 \%$. According to Bentler and Chou (1987), the number of valid samples should be 5-10 times that of the measurement items. There are 15 items in this research, so at least 150 samples are required.

Among the 245 respondents, $51.42 \%(\mathrm{n}=126)$ were females and $48.57 \%$ (119) were males. Further, $24.89 \%(61)$ were aged between 26 and 30, and 23.67\% (58) were aged between 21 and 25. As for their educational background, the majority of them $(65.30 \%)$ attended colleges and universities.

Table 1. Demographic data of research participants

\begin{tabular}{llll}
\hline Item & Sub-item & Counts & Percentage \\
\hline Gender & Female & 126 & $51.42 \%$ \\
Age & Male & 119 & $48.57 \%$ \\
& No more than 20 & 30 & $12.24 \%$ \\
& Between 21 and 25 & 58 & $23.67 \%$ \\
& Between 26 and 30 & 61 & $24.89 \%$ \\
& Between 31 and 35 & 45 & $18.36 \%$ \\
Educational background & Between 36 and 40 & 28 & $11.42 \%$ \\
& 41 and above & 23 & $9.56 \%$ \\
& Senior high school and below & 11 & $4.48 \%$ \\
& Colleges and universities & 160 & $65.30 \%$ \\
& Graduate school & 74 & $30.20 \%$ \\
\hline
\end{tabular}

\subsection{Reliability and Validity Analysis}

\subsubsection{Reliability Analysis}

A variable with a Cronbach's $\alpha$ value of more than 0.7 is considered to have good reliability (Nunnally, 1978). In this study, the Cronbach's $\alpha$ values obtained for the SMIs-followers relationship quality, trust transference, brand attitude, skepticism character, and self-monitoring were $0.875,0.766,0.919,0.710$, and 0.805 respectively. All exceeded 0.7 , indicating that they have good reliability.

\subsubsection{Validity Analysis}

Convergent validity refers to the degree to which questions or tests about similar potential traits truly fall onto the same construct. In this study, the average variance extracted (AVE) was used to examine the average variation explanatory power between the observed and the latent variables. Fornell and Larcker (1981) suggested that AVE should exceed 0.5 and its composite reliability (CR) should exceed 0.6.

The AVE and CR values obtained for the variables of this study were: SMIs-followers relationship quality, $\mathrm{AVE}=0.573, \mathrm{CR}=0.799$; trust transference, $\mathrm{AVE}=0.700, \mathrm{CR}=0.843$; brand attitude, $\mathrm{AVE}=0.736, \mathrm{CR}=0.887$; skepticism character, $\mathrm{AVE}=0.524, \mathrm{CR}=0.767$; and self-monitoring, $\mathrm{AVE}=0.516, \mathrm{CR}=0.778$. All exceeded the standard values indicating good convergent validity.

Discriminant validity refers to the extent to which two constructs that are not related, are truly not correlated with each other. In this study, discriminant validity was measured using the square root of AVE. According to Bagozzi and Yi (1988) and Fornell and Larcker (1981) the construct being measured should be greater than the correlation between every construct to be considered as having good discriminant validity. As shown in Table 2, the square roots of AVE of the present study's variables were greater than the square of the correlation coefficients; thus, all have good discriminant validity. 
Table 2. Comparison between the square of the correlation coefficients and AVE

\begin{tabular}{llllll}
\hline & $\begin{array}{l}\text { Relationship } \\
\text { quality }\end{array}$ & $\begin{array}{l}\text { Trust } \\
\text { transference }\end{array}$ & $\begin{array}{l}\text { Brand } \\
\text { attitude }\end{array}$ & $\begin{array}{l}\text { Skepticism } \\
\text { character }\end{array}$ & Self-monitoring \\
\hline $\begin{array}{l}\text { Relationship quality } \\
\text { Trust transference }\end{array}$ & 0.756 & & & & \\
Brand attitude & $0.640^{* *}$ & 0.700 & & & \\
Skepticism character & $0.735^{* *}$ & $0.764^{* *}$ & 0.836 & & \\
Self-monitoring & $0.185^{* *}$ & $0.149^{*}$ & $0.254^{* *}$ & 0.723 & 0.718 \\
\hline
\end{tabular}

Note. Diagonal values are values of the square root of AVE; * indicates that p-value is less than 0.05 while ** indicates that p-value is less than 0.01 .

\subsection{Path Analysis}

\subsubsection{Relationship Among SMI-Follower Relationship Quality, Trust Transference, and Brand Attitude}

This study used the model 11 in software PROCESS 2.163 (Hayes, 2013) and the bootstrapping method $(\mathrm{M}=5000)$ to verify the mediating and moderating effects; relevant data are listed in Table 3 and Figure 2 . For the relationship between SMI-follower relationship quality and trust transference, the values obtained for regression coefficient and t-value were 2.985 and 3.866 respectively, with a p-value of 0.000 . Since the p-value is less than 0.05 , this means that the explanatory power was significant. Therefore, $\mathrm{H} 1$ is supported; that is, the relationship quality has a positive impact on trust transference indicating that the higher the SMI-follower relationship quality, the more likely the followers will transfer their trust in SMIs to brands that the latter recommend.

As for the relationship between trust transference and brand attitude, the regression coefficient was $0.661, \mathrm{t}$-value was 12.581, and p-value was 0.000 which is less than 0.05 . Therefore, the explanatory power of trust transference to brand attitude reached a significant level, supporting $\mathrm{H} 2$. This means that trust transference exerts a positive impact on brand attitude; that is, the higher the extent to which trust is transferred, the more positive the brand attitude of followers will be.

\subsubsection{The Moderating Effect of Skeptical Character and Self-Monitoring}

Regarding the interaction of skeptical character and relationship quality with trust transference, the regression coefficient was -0.475 , $t$-value was -3.401 , and $p$-value was 0.000 , which is less than 0.05 indicating that advertising skepticism negatively moderates the impact of relationship quality on trust transference. This means that $\mathrm{H} 3$ is supported; that is, a high level of advertising skepticism lowers the relationship quality and the extent of trust transference.

In terms of the influence of self-monitoring on the moderating effect of advertising skepticism on the relationship between SMI-follower relationship quality and trust transference, the values obtained for regression coefficient and t-value were 0.074 and 2.840 respectively, and the p-value was 0.000 . Since the p-value is less than 0.05 , this means that $\mathrm{H} 4$ is supported. When followers' self-monitoring is high, it inhibits their advertising skepticism and strengthens the positive relationship between relationship quality and trust transference.

Table 3. Serial analysis with unstandardized regression coefficients and bootstrapping (m-5,000; Hayes, 2013)

\begin{tabular}{|c|c|c|c|c|c|c|}
\hline Outcome & $\mathrm{B}(\mathrm{SE})$ & & T-value & P-value & LLCI & ULCI \\
\hline Trust transference constant & $-11.525 * * *$ & (3.696) & -3.118 & 0.002 & -18.807 & -4.2440 \\
\hline Relationship quality (RQ) & $2.985 * * *$ & $(0.772)$ & 3.866 & 0.000 & 1.464 & 4.5060 \\
\hline Skepticism character (SP) & $2.613 * * *$ & $(0.659)$ & 3.965 & 0.000 & 1.314 & 3.9110 \\
\hline $\mathrm{RQ}$ *SP & $-0.475 * * *$ & $(0.139)$ & -3.401 & 0.000 & -0.7003 & -0.1358 \\
\hline Self-Monitoring & $2.472 * * *$ & $(0.691)$ & 3.574 & 0.000 & 1.1090 & 3.8340 \\
\hline $\mathrm{RQ} * \mathrm{SM}$ & $-0.418^{* * *}$ & $(0.143)$ & -2.918 & 0.003 & -0.7003 & -0.1350 \\
\hline $\mathrm{SP} * \mathrm{SM}$ & $-0.413 * * *$ & $(0.124)$ & -3.319 & 0.001 & -0.6590 & -0.1680 \\
\hline $\mathrm{RQ} * \mathrm{SP} * \mathrm{SM}$ & $0.074 * * *$ & $(0.026)$ & 2.840 & 0.004 & 0.0220 & 0.1250 \\
\hline Brand attitude constant & 0.410 & $(0.224)$ & 1.8240 & 0.169 & -0.0320 & 0.8520 \\
\hline Trust transference & $0.661 * * *$ & $(0.052)$ & 12.581 & 0.000 & 0.5580 & 0.7664 \\
\hline Relationship quality & $0.228 * * *$ & $(0.035)$ & 6.3430 & 0.000 & 0.1530 & 0.2920 \\
\hline
\end{tabular}

Note. ${ }^{* *}$ indicates $\mathrm{p}$-value $<0.01$ while * suggests $\mathrm{p}$-value $<0.05$. 


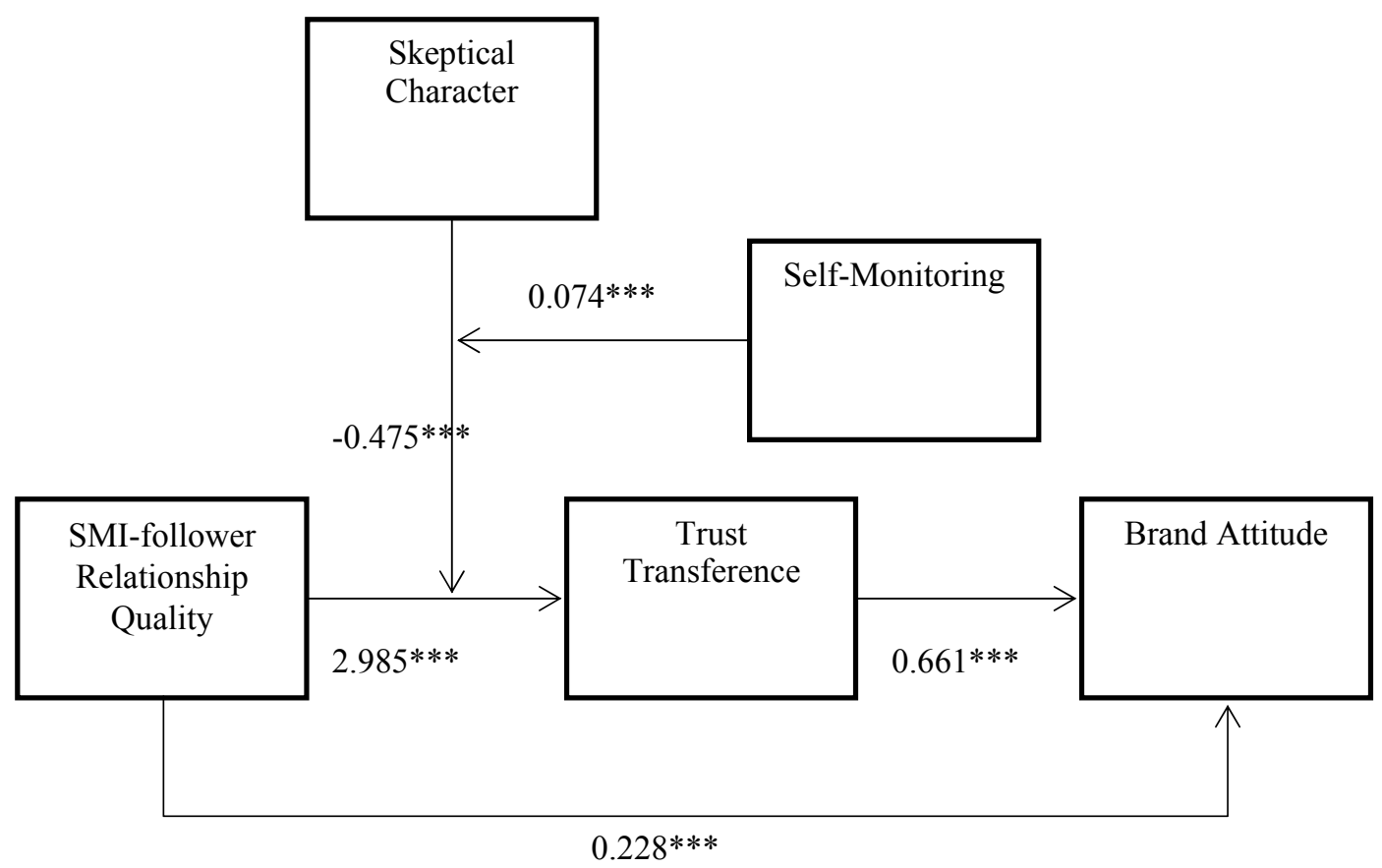

Figure 2. Results of path analysis

\section{Conclusion and Suggestion}

\subsection{Conclusion}

This study explored the relationship among SMI-follower relationship quality, trust transference, advertising skepticism, self-monitoring, and brand attitude. Based on the results, this study concludes the following: (1) The higher the SMI-follower relationship quality, the easier it is to generate trust transference; (2) trust transference is a partial mediator, which has a positive impact on relationship quality and brand attitude; (3) followers' high level of advertising skepticism negatively affects the relationship between SMI-follower relationship quality and trust transference; and (4) consumers' high degree of self-monitoring inhibits the negative moderating effect of advertising skepticism on SMI-follower relationship quality and trust transference.

The empirical results showed that a strong relationship between SMIs and followers enables the latter to transfer their trust in the former to the recommended products. To build a good relationship, one should work on it from three aspects, namely trust, commitment, and satisfaction. Therefore, SMIs have to ensure that the content of their posts is authentic, and should not casually recommend products to their followers merely for business benefits. Once the followers sense that the SMI is only after the profit, they are likely to end their relationship with the SMI. SMIs are suggested to stick to their original intention and provide valuable contents to satisfy their followers. When endorsing brands, SMIs must confirm whether the product meets the needs of their followers. Therefore, to enable the SMI economy to last, SMIs should pay close attention to the quality of their relationship with their followers.

In addition, the results showed that advertising skepticism negatively moderates the impact of relationship quality on trust transference. The higher the advertising skepticism, the higher the relationship quality is and the lower the trust transference is. A high level of self-monitoring inhibits the negative effect of SMI-follower relationship quality on trust transference; that is, the high self-monitoring trait of the follower will positively influence the recommendation of the SMI; followers will like and purchase the recommended product, and even recommend them to others.

\subsection{Management Implications}

\subsubsection{SMIs Advised to Improve SMI-Follower Relationship Quality}

SMIs have advantages over celebrities in terms of having a diverse background and knowledge, closer affinity with followers, and varied platforms that increase their public reach. Therefore, SMIs have easier access to followers than celebrities. In addition to a specific audience, they are able to cultivate loyal followers through 
long-term efforts. This research confirmed that the higher the SMI-follower relationship quality, the more effective their recommendation will be. If SMIs mean to commercialize their relationship with followers via advertising, they would need to maintain their professionalism and have great interaction with followers to retain their popularity.

Moreover, SMIs are advised to get to know their followers. This research found that followers with high self-monitoring are more likely to be influenced by SMIs. If their followers have a high level of advertising skepticism, they should be careful in advertising via their posts. SMIs can get to know the personality and characteristics of their followers through daily interaction, questionnaire survey, lucky draws, or with the aid of organizations. In brief, the better SMIs know their followers, the more likely it is to increase their conversion rate.

\subsubsection{The Way Brand Manufacturers Select SMIs}

This empirical study revealed that relationship quality has a partial mediating effect on trust transference. In the context of SMI economy, how brand manufacturers select the right SMIs as their brand spokespeople and optimize the return on their investments in advertising is a key issue. To help brand manufacturers solve this problem, a growing number of websites provide social media influencer rankings, such as NoxInfluencer, socialblade.com, and KOL Radar, which serve as references for them in terms of SMI selection.

In addition to the number of followers and viewing rate, brand manufacturers can also select SMIs based on the quality of their relationship with followers, based on their recent posts, audience groups, and interaction rate. When looking for SMIs to cooperate with, brand manufacturers should take into account the extent to which SMIs are related to the positioning, product, and target market of the brand, the SMI-follower relationship quality, and whether the number of ads is acceptable for the followers of SMIs who they mean to cooperate with. Otherwise, the investment of brand manufacturers may not reach the target consumers accurately, and may even cause the disgust of potential consumers.

\subsection{Research Limitations of Present Research and Suggestions for Future Research}

This study employed two personality traits, i.e., self-monitoring and advertising skepticism, as moderators. However, humans are complex, and may have other traits that can better reflect their thoughts and behaviors.

It is suggested that subsequent research explore whether SMI-follower relationship quality shows an inverted U-shaped curve after SMIs endorse certain brands; in other words, they should investigate whether followers will be averse to SMIs because of excessive endorsement, and even destroy their relationship.

\section{References}

Aaker, J., \& Fournier, S. (1995). A brand as a character, a partner and a person: Three perspectives on the question of brand personality. In R. K. Frank \& S. Mita (Eds.), NA - Advances in Consumer Research (Vol. 22, pp. 391-395). Provo, UT: Association for Consumer Research.

Arjun, C. M., \& Holbrook, B. (2001). The Chain of Effects from Brand Trust and Brand Affect to Brand Performance: The Role of Brand Loyalty. Journal of Marketing, 65, 81-93. https://doi.org/10.1509/jmkg.65.2.81.18255

Armstrong, G., \& Kolter, P. (2000). Marketing (5th ed.). Prentice-Hall, Englewood Cliffs, NJ.

Assael, H. (2004). Consumer Behavior: A Strategic Approach, Hunghton Mifflin Company. Boston, MA.

Audrezet, A., De Kerviler, G., \& Moulard, J. G. (2018). Authenticity under threat: When social media influencers need go beyond self-presentations. Journal of Business Research, 117, 1-13. https://doi.org/10.1016/j.jbusres.2018.07.008

Bagozzi, R., \& Yi, Y. (1988). On the evaluation of structural equation models. Academy of Marketing Science, 16(1), 74-94. https://doi.org/10.1007/BF02723327

Becherer, R. C., \& Richard, L. M. (1978). Self-monitoring as a moderating variable in consumer behavior. Journal of Consumer Research, 5(3), 159-162. https://doi.org/10.1086/208726

Bedeian, A. G., \& Day, D. V. (2004). Can chameleons lead? The Leadership Quarterly, 15(5), 687-718. https://doi.org/10.1016/j.leaqua.2004.07.005

Bentler, P. M., \& Chou, C. P. (1987). Practical issues in structural modeling. Sociological Methods \& Research, 16(1), 78-117. https://doi.org/10.1177/0049124187016001004

Bergami, M., \& Bagozzi, R. P. (2000). Self-categorization, affective commitment and group self-esteem as 
distinct aspects of social identity in the organization. British Journal Social Psychology, 39(4), 555-577. https://doi.org/10.1348/014466600164633

Bikhchandani, S., De Vries, S., Schummer, J., \& Vohra, R. V. (2011). An Ascending Vickrey Auction for Selling Bases of a Matroid. Operations Research, 59(2), 400-413. https://doi.org/10.1287/opre.1100.0888

Boerman, S. C. (2020). The effects of the standardized Instagram disclosure for micro- and meso-influencers. Computers in Human Behavior, 103, 199-207. https://doi.org/10.1016/j.chb.2019.09.015

Boush, D. M., Friestad, M., \& Rose, G. M. (1994). Adolescent Skepticism toward TV Advertising and Knowledge of Advertiser Tactics. Journal of Consumer Research, 21(1), 165-175. https://doi.org/10.1086/209390

Brucks, M., Armstrong, G. M., \& Goldberg, M. E. (1988). Children's Use of Cognitive Defenses Against Television Advertising: A Cognitive Response Approach. Journal of Consumer Research, 14(4), 471-482. https://doi.org/10.1086/209129

Campbell, C., \& Farrell, J. R. (2020). More than meets the eye: The functional components underlying influencer marketing. Business Horizons, 63(4), 469-479. https://doi.org/10.1016/j.bushor.2020.03.003

Campbell, M. C., \& Kirmani, A. (2000). Consumers' Use of Persuasion Knowledge: The Effects of Accessibility and Cognitive Capacity on Perceptions of an Influence Agent. Journal of Consumer Research, 27(1), 69-83. https://doi.org/10.1086/314309

Chu, S.-C., Kamal, S., \& Kim, Y. (2019). Re-examining of consumers' responses toward social media advertising and purchase intention toward luxury products from 2013 to 2018: A retrospective commentary. Journal of Global Fashion Marketing, 10(1), 81-92. https://doi.org/10.1080/20932685.2018.1550008

Crosby, L. A., Evans, K. R., \& Cowles, D. (1990). Relationship quality in services selling: An interpersonal influence perspective. Journal of Marketing, 54(3), 68-81. https://doi.org/10.1177/002224299005400306

Darby, M. R., \& Karni, E. (1973). Free Competition and the Optimal Amount of Fraud. Journal of Law and Economics, 16(1), 67-88. https://doi.org/10.1086/466756

De Veirman, M., Cauberghe, V., \& Hudders, L. (2017). Marketing through Instagram influencers: The impact of number of followers and product divergence on brand attitude. International Journal of Advertising, 36(5), 798-828. https://doi.org/10.1080/02650487.2017.1348035

DeBono, K. G. (2006). Self - monitoring and consumer psychology. Journal of Personality, 74(3), 715-738. https://doi.org/10.1111/j.1467-6494.2006.00390.x

Dhanesh, G. S., \& Duthler, G. (2019). Relationship management through social media influencers: Effects of followers awareness of paid endorsement. Public Relationship Review, 45(3), 1-13. https://doi.org/10.1016/j.pubrev.2019.03.002

Doney, P. M., \& Cannon, J. P. (1997). An examination of the nature of trust in buyer-seller relationships. Journal of Marketing, 61(2), 35-51. https://doi.org/10.1177/002224299706100203

Enke, N., \& Borchers, N. S. (2019). Social Media Influencers in Strategic Communication: A Conceptual Framework for Strategic Social Media Influencer Communication. International Journal of Strategic Communication, 13(4), 261-277. https://doi.org/10.1080/1553118X.2019.1620234

Feick, L., \& Gierlb, H. (1996). Skepticism about advertising: A comparison of East and West German consumers. International Journal of Research in Marketing, 13(3), 227-235. https://doi.org/10.1016/0167-8116(96)00009-2

Ferguson, G., Lau, K. C., \& Phau, I. (2016). Brand personality as a direct cause of brand extension success: Does self-monitoring matter? Journal of Consumer Marketing, 33(5), 343-353. https://doi.org/10.1108/JCM-04-2014-0954

Fine, L. M., \& Schumann, D. W. (1992). The nature and role of salesperson perceptions: The interactive effects of salesperson/customer personalities. Journal of Consumer Psychology, 1(3), 285-296. https://doi.org/10.1016/S1057-7408(08)80040-X

Fishbein, M., \& Ajzen, L. (1975). Belief, attitude, intention and behavior: An introduction to theory and research. Reading, MA: Addison-Wesley. California, US.

Fornell, C., \& Laracker, D. (1981). Evaluating structural models with unobservable variables and measurement error. Journal of Marketing Research, 18, 39-50. https://doi.org/10.1177/002224378101800104 
Fournier, S. (1998). Consumers and their brands: Developing relationship theory in consumer research. Journal of Consumer Research, 24(4), 343-373. https://doi.org/10.1086/209515

Ganesan, S., \& Hess, R. (1997). Dimensions and levels of trust: Implications for commitment to a relationship. Marketing Letters, 8(4), 439-448. https://doi.org/10.1023/A:1007955514781

Gangestad, S. W., \& Snyder, M. (2000). Self-monitoring: Appraisal and reappraisal. Psychological Bulletin, 126(4), 530-555. https://doi.org/10.1037/0033-2909.126.4.530

Hayes, A. F. (2013). Introduction to Mediation, Moderation, and Conditional Process Analysis: A Regression-Based Approach. New York, NY: The Guilford Press.

Howard, J. A. (1989). Consumer Behavior in Marketing Strategy. Prentice Hall, Englewood, Cliffs, NJ.

Hwang, Y., \& Jeong, S.-H. (2016). This is a sponsored blog post, but all opinions are my own: The effects of sponsorship disclosure on responses to sponsored blog posts. Computers in Human Behavior, 62, 528-535. https://doi.org/10.1016/j.chb.2016.04.026

Itani, O. S., Kassar, A.-N., \& Loureiro, S. M. C. (2019). Value get, value give: The relationships among perceived value, relationship quality, customer engagement, and value consciousness. International Journal of Hospitality Management, 80, 78-90. https://doi.org/10.1016/j.ijhm.2019.01.014

Jenkins, J. M. (1993). Self - monitoring and turnover: The impact of personality on intent to leave. Journal of Organizational Behavior, 14(1), 83-91. https://doi.org/10.1002/job.4030140108

Johnson, D., \& Grayson, K. (2005). Cognitive and affective trust in service relationships. Journal of Business Research, 58(4), 500-507. https://doi.org/10.1016/S0148-2963(03)00140-1

Kauppinen-Räisänen, H., Björk, P., Lönnström, A., \& Jauffret, M. N. (2018). How consumers' need for uniqueness, self-monitoring, and social identity affect their choices when luxury brands visually shout versus whisper. Journal of Business Research, 84, 72-81. https://doi.org/10.1016/j.jbusres.2017.11.012

Ki, C., Cuevas, L. M., Chong, S. M., \& Lim, H. (2020). Influencer Marketing: Social media influencers as human brands attaching to followers and yielding positive marketing results by fulfilling needs. Journal of Retailing and Consumer Services, 55, 102-133. https://doi.org/10.1016/j.jretconser.2020.102133

Ki, C.-W. C., \& Kim, Y.-K. (2019). The mechanism by which social media influencers persuade consumers: The role of consumer's desire to mimic. Psychology Marketing, 36(10), 905-922. https://doi.org/10.1002/mar.21244

Kim, D. H., Seely, N. K., \& Jung, J. H. (2017). Do you prefer, Pinterest or Instagram? The role of image-sharing SNSs and self-monitoring in enhancing ad effectiveness. Computers in Human Behavior, 70, 535-543. https://doi.org/10.1016/j.chb.2017.01.022

Kumar, V., \& Pansari, A. (2016). Competitive advantage through engagement. Journal of Marketing Research, 53(4), 497-514. https://doi.org/10.1509/jmr.15.0044

Lavine, H., \& Snyder, M. (1996). Cognitive processing and the functional matching effect in persuasion: The mediating role of subjective perceptions of message quality. Journal of Experimental Social Psychology, 32(6), 580-604. https://doi.org/10.1006/jesp.1996.0026

Lee, E.-B., Lee, S.-G., \& Yang, C.-G. (2017). The influences of advertisement attitude and brand attitude on purchase intention of smartphone advertising. Industrial Management and Data Systems, 117(6), 1011-1036. https://doi.org/10.1108/IMDS-06-2016-0229

Lee, J., \& Hong, I. B. (2019). Consumer's electronic word-of-mouth adoption: The trust transference perspective. International Journal of Electronic Commerce, 23(4), 595-627. https://doi.org/10.1080/10864415.2019.1655207

Lennox, R. D., \& Wolfe, R. N. (1984). Revision of the self-monitoring scale. Journal of Personality and Social Psychology, 46(6), 1349-1364. https://doi.org/10.1037/0022-3514.46.6.1349

Lippa, R. (1976). Expressive control and the leakage of dispositional introversion-extraversion during role - played teaching. Journal of Personality, 44(4), 541-559. https://doi.org/10.1111/j.1467-6494.1976.tb00137.x

Liu, L., Lee, M. K. O., Liu, R., \& Chen, J. (2018). trust transference in social media brand communities: The role of consumer engagement. International Journal of Information Management, 41, 1-13. https://doi.org/10.1016/j.ijinfomgt.2018.02.006 
Lou, C., \& Yuan, S. (2019). Influencer marketing: How message value and affect consumer trust of branded content on social media. Journal of Interactive Advertising, 19(1), 58-73. https://doi.org/10.1080/15252019.2018.1533501

Lovelock, C. H. (1983). Classifying services to gain strategic marketing insights. Journal of Marketing, 47(3), 9-20. https://doi.org/10.1177/002224298304700303

MacKenzie, S. B., Lutz, R. J., \& Belch, G. E. (1986). The role of attitude toward the ad as a mediator of advertising effectiveness: A test of competing explanations. Journal of Marketing Research, 23(2), 130-143. https://doi.org/10.1177/002224378602300205

Mangleburg, T. F., \& Bristol, T. (1998). Socialization and adolescents' skepticism toward advertising. Journal of Advertising, 27(3), 11-21. https://doi.org/10.1080/00913367.1998.10673559

McCracken, G. (1989). Who Is the Celebrity Endorser? Cultural Foundations of the Endorsement Process. Journal of Consumer Research, 16(3), 310-321. https://doi.org/10.1086/209217

McGuire, W. J. (1989). Theoretical Foundation of Campaigns, in Public Communication Campaign (R. Rice \& C. K. Atkins eds., 2nd ed., pp. 43-65) Newbury Park, CA: Sage Publications.

Milliman, R. E., \& Fugate, D. L. (1988). Using Trust-Transference as a Persuasion Technique: An Empirical Field Investigation. Journal of Personal Selling and Sales Management, 8(2), 1-7. https://doi.org/10.1080/08853134.1988.10754486

Moorman, C., Deshpande, R., \& Zalman, G. (1993). Factors affecting trust in market research relationships. Journal of Marketing, 57(1), 81-101. https://doi.org/10.1177/002224299305700106

Morgan, R. M., \& Hunt. S. D. (1994). The commitment-trust theory of relationship marketing. Journal of Marketing, 58(3), 20-38. https://doi.org/10.1177/002224299405800302

Moye, L. N., \& Kincade, D. H. (2003). Shopping orientation segments: Exploring differences in store patronage and attitudes toward retail store environments among female apparel consumers. International Journal of Consumer Studies, 27(1), 58-71. https://doi.org/10.1046/j.1470-6431.2003.00260.x

Nantel, J. A., \& Strahle, W. (1986). The Self-Monitoring Concept: A Consumer Behavior Perspective. In J. L. Richard (Ed.), NA - Advances in Consumer Research (Vol. 13, pp. 83-87). Provo, UT: Association for Consumer Research.

Nunnally, J. C. (1978). Psychometric Theory. New York: McGraw-Hill.

O'Cass, A. (2000). A Psychometric Evaluation of a Revised Version of the Lennox and Wolfe Revised

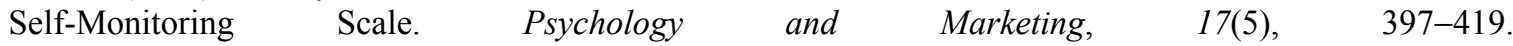
https://doi.org/10.1002/(SICI)1520-6793(200005)17:5<397::AID-MAR3>3.0.CO;2-D

O’Shaughnessy, J., \& O'Shaughnessy, N. (2004). Persuasion in Advertising. Taylor \& Francis Group, NewYork.

Obermiller, C., \& Spangenberg, E. (1998). Development of a Scale to Measure Consumer Skepticism Toward Advertising. Journal of Consumer Psychology, 7(2), 159-186. https://doi.org/10.1207/s15327663jcp0702_03

Obermiller, C., Spangenberg, E., \& MacLachlan, D. L. (2005) Ad Skepticism: The consequences of disbelief. Journal of Advertising, 34(3), 7-17. https://doi.org/10.1080/00913367.2005.10639199

Oliver, R. L. (1997). Satisfaction: A behavioral perspective on the consumer. Routledge, NY.

Pornsakulvanich, V. (2018). Excessive use of Facebook: The influence of self-monitoring and Facebook usage on social support. Journal of Social Sciences, 39(1), 116-121. https://doi.org/10.1016/j.kjss.2017.02.001

Rosenberg, M. J., Hovland, C. I., McGuire, W. J., Abelson, R. P., \& Brehm, J. W. (1960). Attitude organization and change: An analysis of consistency among attitude components. Yale studies in attitude and communication. Yale University Press.

Santouridis, I., \& Veraki, A. (2017). Customer relationship management and customer satisfaction: The mediating role of relationship quality. Total Quality Management and Business Excellence, 28(9-10), 1122-1133. https://doi.org/10.1080/14783363.2017.1303889

Snyder, M. (1979). Self-monitoring processes. Advances in Experimental Social Psychology, 12, 85-128. https://doi.org/10.1016/S0065-2601(08)60260-9

Stewart, K. J. (2003). Trust transfer on the World Wide Web. Organization Science, 14(1), 5-17. 
https://doi.org/10.1287/orsc.14.1.5.12810

Stoldt, R., Wellman, M., \& Ekdale, B. (2019). Professionalizing and Profiting: The rise of intermediaries in the social media influencer industry. Social Media Society, 5(1), 1-11. https://doi.org/10.1177/2056305119832587

Stubb, C., \& Colliander, J. (2019). This is not sponsored content- the effects of impartiality disclosure and e-commerce landing pages on consumer responses to social media influencer posts. Computers in Human Behavior, 98, 210-222. https://doi.org/10.1016/j.chb.2019.04.024

Tan, S. J. (2002). Can consumers' skepticism be mitigated by claim objectivity and claim extremity? Journal of Marketing Communications, 8(1), 45-64. https://doi.org/10.1080/13527260210122097

Thibau, J. W., \& Kelly, H. H. (1959). The Social Psychology of Groups. John Wiley \& Son, Inc. NY, US.

Thomson, M. (2006). Human brand: Investigating antecedents to consumer strong attachments to celebrity. Journal of Marketing, 70(3), 104-119. https://doi.org/10.1509/jmkg.70.3.104

Wang, S. J., Hsu, C. P., Huang, H. C., \& Chen, C. L. (2015). How readers' perceived self-congruity and functional congruity affect bloggers' informational influence: Perceived interactivity as a moderator. Online Information Review, 39(4), 537-555. https://doi.org/10.1108/OIR-02-2015-0063

Yuan, S., \& Lou, C. (2020). How social media influencers foster relationships with followers: The roles of source credibility and fairness in parasocial relationship and product interest. Journal of Interactive Advertising, 20(2), 133-147. https://doi.org/10.1080/15252019.2020.1769514

Zhang, X., Ko, M., \& Carpenter, D. (2016). Development of a scale to measure skepticism toward electronic word-of-mouth. Computers in Human Behavior, 56, 198-208. https://doi.org/10.1016/j.chb.2015.11.042

Zhao, J. D., Huang, J. S., \& Su, S. (2019). The effects of trust on consumers' continuous purchase intention in C2C social commerce: A trust transference perspective. Journal of Retailing and Consumer Services, 50, 42-49. https://doi.org/10.1016/j.jretconser.2019.04.014

\section{Copyrights}

Copyright for this article is retained by the author, with first publication rights granted to the journal.

This is an open-access article distributed under the terms and conditions of the Creative Commons Attribution license (http://creativecommons.org/licenses/by/4.0/). 